\title{
Needle Fracture, a Rare Endoscopic Ultrasound-Guided Fine-Needle Aspiration Complication and Why?
}

\author{
Kook Hyun Kim, Sung Bum Kim and Tae Nyeun Kim \\ Division of Gastroenterology and Hepatology, Department of Internal Medicine, Yeungnam University College of Medicine, Daegu,
} Korea

Endoscopic ultrasound-guided fine-needle aspiration (EUSFNA) is the procedure of choice for tissue diagnoses of the gastrointestinal tract. The most common complications are bleeding, abdominal pain, and pancreatitis, with an overall rate of $0.98 \%{ }^{1}$ Needle fracture is a rare complication. ${ }^{2-5}$

A 77-year-old man was transferred to our hospital because of bowel obstruction. Abdominal computed tomography showed a markedly distended stomach due to a duodenal mass, causing gastric outlet obstruction. Histopathology of an endoscopic biopsy specimen obtained at outside hospital re- vealed chronic ulceration. Upper endoscopy failed to provide clear visualization of the obstructive lesion due to the duodenal deformity (Fig. 1A). After changing to a side-view scope, a round mass with a smooth surface and soft consistency was seen obstructing the duodenal lumen, causing passage failure of the scope. Under conscious sedation, the radial and linear EUS (GF-UCT260; Olympus Ltd., Tokyo, Japan) demonstrated a poorly demarcated $28 \times 27 \mathrm{~mm}$ sized hypoechoic mass in the duodenum. A 22-gauge needle (Acquire; Boston Scientific, Spencer, IN, USA) was used for tissue acquisition (Fig. 1B, C).
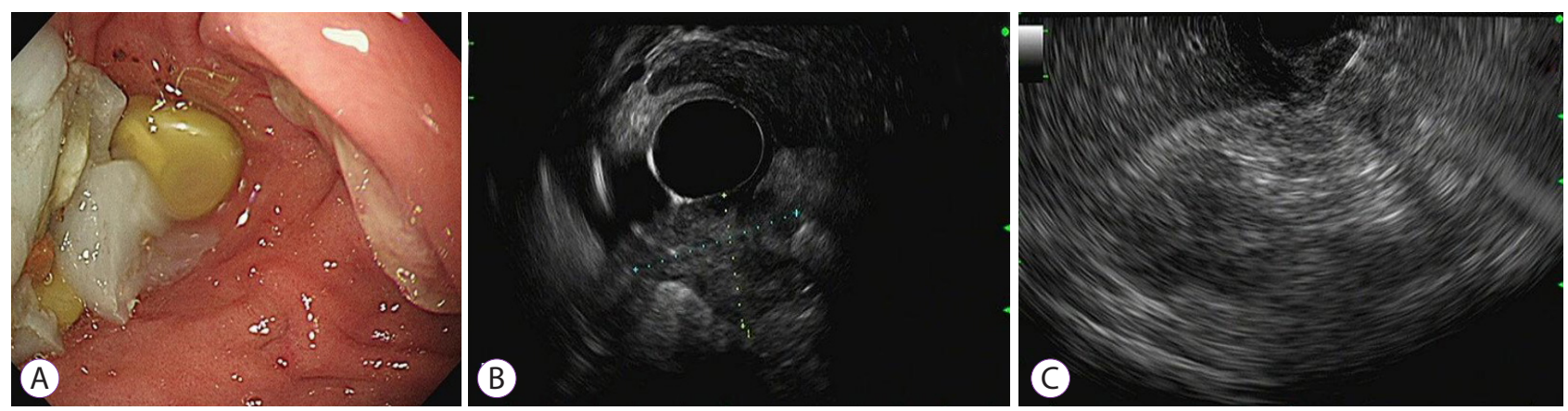

Fig. 1. (A) Upper endoscopy shows an obstructive lesion of the duodenum and a duodenal deformity. (B) Radial endoscopic ultrasound reveals a $27 \times 28 \mathrm{~mm}$ hypoechoic mass. (C) A 22-gauge needle (Acquire; Boston Scientific, Spencer, IN, USA) is used to puncture the mass, with maximal erection of the elevator.

Received: May 9, 2020 Revised: June 27, 2020

Accepted: June 27, 2020

Correspondence: Kook Hyun Kim

Division of Gastroenterology and Hepatology, Department of Internal Medicine, Yeungnam University College of Medicine, 170 Hyeonchung-ro, Nam-gu, Daegu 42415 , Korea Tel: +82-53-620-3576, Fax: +82-53-654-8386, E-mail: kimkh@yu.ac.kr

ORCID: https://orcid.org/0000-0001-7786-7882

(cc) This is an Open Access article distributed under the terms of the Creative Commons Attribution Non-Commercial License (http://creativecommons.org/licenses/bync/3.0) which permits unrestricted non-commercial use, distribution, and reproduction in any medium, provided the original work is properly cited. 


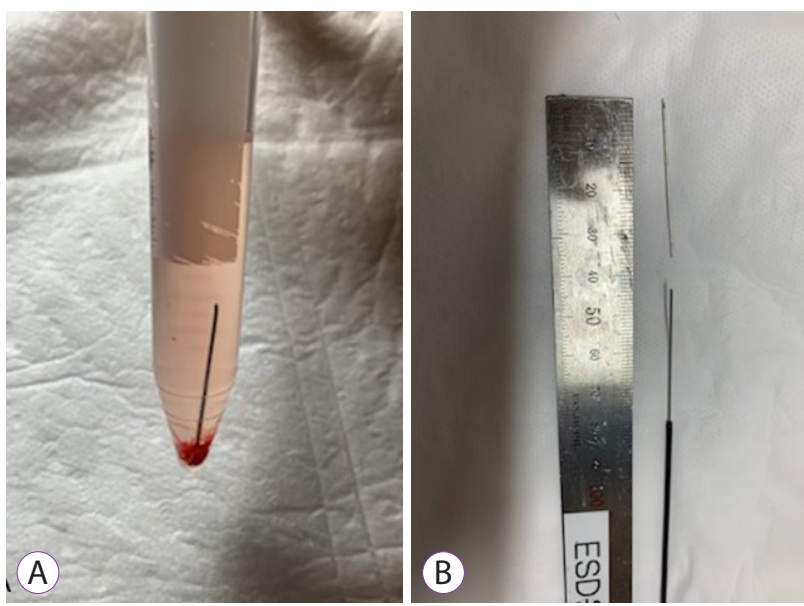

Fig. 2. (A) A fragment of the fractured needle in the saline tube is visualized. (B) The length of the extracted fragment is approximately $4 \mathrm{~cm}$.

The tip of the scope was torqued, and the elevator was maximally erected for targeting. The first two punctures were to some extent successful, with small amounts of tissue sampling. Once punctured, to-and-fro movements were performed more than 10 times, including the fanning technique. On the third puncture, the scope was suddenly pushed back into the stomach, and the needle tip was not visualized on the screen, indicating it was wedged in the duodenal mass, and the needle body extending from the pylorus to the antrum was visualized in the stomach. The needle handle was locked, and several attempts to withdraw the needle into the sheath failed. With a forceful pulling of the needle backward with firm grip, the needle was slipped into the sheath, without any complication. The aspirated sample was being pushed and slid into the saline tube using the stylet, and a fragment of the fractured needle was dropped in the tube (Fig. 2A, B). Finally, the patient was diagnosed with duodenal cancer based on the pathologic confirmation of adenocarcinoma, and subsequently, a metal stent was placed into the stenotic lesion because of the patient's refusal to undergo surgery.

Table 1 shows a summary of previous reports associated with needle fractures during EUS-FNA. ${ }^{2-5}$ All previous cases of fractures occurred during the second or third passage of the needle into the target lesion, but in this case, it occurred after complete retrieval of the needle from the linear scope. The length of the fractured fragment was approximately $4 \mathrm{~cm}$, similar to all previous cases except one. ${ }^{2}$ Needle fractures have occurred in needle calibers ranging from 22 to 19 gauge. The accumulated physical force might have attributed to needle breakage. Plausible explanations of this phenomenon are as follows. First, a maximal strain is exerted on the specific point of the needle when the elevator is erected to the greatest degree possible for performing EUS-FNA. Second, the repeated to-and-fro movement and/or the fanning technique can influ-

Table 1. A Summary of Cases of Needle Fractures Associated with Endoscopic Ultrasound-Guided Fine-Needle Aspiration

\begin{tabular}{|c|c|c|c|c|c|c|c|c|}
\hline Study & $\begin{array}{l}\text { Needle size, type } \\
\text { (manufacturer) }\end{array}$ & $\begin{array}{l}\text { Numbers of } \\
\text { puncture }\end{array}$ & $\begin{array}{l}\text { Location of } \\
\text { target lesion }\end{array}$ & $\begin{array}{l}\text { Causes of } \\
\text { EUS-FNA }\end{array}$ & $\begin{array}{l}\text { Length of } \\
\text { fragment } \\
\text { needle }\end{array}$ & $\begin{array}{l}\text { Elevator } \\
\text { use }\end{array}$ & $\begin{array}{l}\text { Fanning } \\
\text { method }\end{array}$ & $\begin{array}{l}\text { Removal } \\
\text { method of } \\
\text { fragmented } \\
\text { needle }\end{array}$ \\
\hline $\begin{array}{l}\text { Dewitt et al. } \\
(2011)^{4}\end{array}$ & $\begin{array}{l}\text { 19-gauge, EchoTip Ultra } \\
\text { (Cook Medical) }\end{array}$ & 3rd pass & $\begin{array}{l}\text { Body of pan- } \\
\text { creas }\end{array}$ & $\begin{array}{l}\text { Pancreati- } \\
\text { cojejunal } \\
\text { stricture }\end{array}$ & $4 \mathrm{~cm}$ & N/A & N/A & Surgery \\
\hline $\begin{array}{l}\text { Adamowicz } \\
\text { et al. }(2016)^{5}\end{array}$ & $\begin{array}{l}\text { 22-gauge, Expect Slimline } \\
\text { (Boston Scientific) }\end{array}$ & 2nd pass & $\begin{array}{l}\text { Subcarinal } \\
\text { lymph node }\end{array}$ & $\begin{array}{l}\text { Lymphade- } \\
\text { nopathy at } \\
\text { hilum }\end{array}$ & $6 \mathrm{~cm}$ & N/A & Yes & $\begin{array}{l}\text { Polypectomy } \\
\text { snare }\end{array}$ \\
\hline $\begin{array}{l}\text { El Hajj et al. } \\
(2018)^{3}\end{array}$ & $\begin{array}{l}\text { 22-gauge, Expect (Boston } \\
\text { Scientific) }\end{array}$ & 3rd pass & $\begin{array}{l}\text { Head of pan- } \\
\text { creas }\end{array}$ & $\begin{array}{l}\text { Pancreatic } \\
\text { mass }\end{array}$ & $4 \mathrm{~cm}$ & $\mathrm{~N} / \mathrm{A}$ & N/A & $\begin{array}{c}\text { Alligator jaw } \\
\text { forceps }\end{array}$ \\
\hline $\begin{array}{l}\text { Sasaki et al. } \\
(2018)^{2}\end{array}$ & $\begin{array}{l}\text { 20-gauge, EchoTip Pro- } \\
\text { Core (Cook Medical) }\end{array}$ & 3rd pass & $\begin{array}{l}\text { Uncinate of } \\
\text { pancreas }\end{array}$ & $\begin{array}{l}\text { Pancreatic } \\
\text { mass }\end{array}$ & $\begin{array}{c}8 \mathrm{~mm}^{\mathrm{a}}{ }^{-} \\
\text {(side hole } \\
\text { point) }\end{array}$ & N/A & N/A & Failed \\
\hline $\begin{array}{l}\text { Our case } \\
(2020)\end{array}$ & $\begin{array}{l}\text { 22-gauge, Acquire (Bos- } \\
\text { ton Scientific) }\end{array}$ & 3rd pass & $\begin{array}{l}\text { 2nd portion of } \\
\text { duodenum }\end{array}$ & $\begin{array}{l}\text { Duodenal } \\
\text { mass }\end{array}$ & $4 \mathrm{~cm}$ & Yes & Yes & Not required \\
\hline
\end{tabular}

EUS-FNA, endoscopic ultrasound-guided fine-needle aspiration; N/A, not available.

a) The needle breakage occurred at the point of a side hole of the needle. 
ence the curved point of the needle physically vulnerable for breakage. Finally, the forceful maneuver to retrieve the needle into the sheath might aggravate the maximal resistance force on the bent point, as in our case. It is presumed that in our case, unusual breakage of the needle might be mainly caused by combined factors, including extreme bending of the needle and vigorous retrieval maneuver of the needle.

This is the first report in the literature on a needle fracture during EUS-FNA in Korea. We informed the manufacturer about the accidental needle fracture for further analyses. With the recently increasing necessity for EUS-FNA, clinicians must be aware of the rare but potential risk of needle fractures when excessive needle bending or multiple punctures are required with numerous to-and-fro motions for the tissue aspiration, in particular, of the duodenal second portion or uncinate process of the pancreas. Furthermore, in cases of duodenal invasion, endoscopic biopsy should be performed initially, if available, to minimize EUS-FNA-associated complications.

Conflicts of Interest

The authors have no potential conflicts of interest.

Funding

None.
Author Contributions

Conceptualization: Kook Hyun Kim

Investigation: KHK

Supervision: Tae Nyeun Kim

Writing-review\&editing: Sung Bum Kim

ORCID

Kook Hyun Kim:

Sung Bum Kim:

Tae Nyeun Kim:

https://orcid.org/0000-0001-7786-7882

https://orcid.org/0000-0001-8447-2176

https://orcid.org/0000-0003-4178-2056

\section{REFERENCES}

1. Wang KX, Ben QW, Jin ZD, et al. Assessment of morbidity and mortality associated with EUS-guided FNA: a systematic review. Gastrointest Endosc 2011;73:283-290.

2. Sasaki T, Kanata R, Sasahira N. Needle fracture during endoscopic ultrasound-guided fine-needle aspiration using a needle with a side hole. Endosc Int Open 2018;6:E553-E557.

3. El Hajj II, Gromski MA, Lehman GA, Easler JJ, Sherman S. Accidental fracture of an EUS-FNA needle. Gastrointest Endosc 2018;87:891-893.

4. DeWitt J, Sherman S, Lillemoe KD. Fracture of an EUS-guided FNA needle during an attempted rendezvous for an inaccessible pancreatic duct. Gastrointest Endosc 2011;73:171-173.

5. Adamowicz B, Manière T, Déry V, Désilets É. Needle fracture during endoscopic ultrasound-guided fine-needle aspiration of suspicious thoracic lymph nodes. Case Rep Med 2016;2016:2526789. 